\title{
KAJIAN YURIDIS SANKSI PIDANA TERHADAP AYAH SEBAGAI PELAKU TINDAK PIDANA PEMERKOSAAN MENURUT QANUN NOMOR 6 TAHUN 2014
}

\author{
Liza Agnesta Krisna \\ Dosen Fakultas Hukum Universitas Samudra (UNSAM) \\ Meurandeh-Langsa \\ Email: agnes_krisna@ymail.com
}

\begin{abstract}
Abstrak
Tujuan penelitian ini adalah untuk mengetahui sanksi hukum pidana terhadap ayah sebagai pelaku tindak pidana pemerkosaan menurut Undang-undang Nomor 35 Tahun 2014 tentang Perubahan Atas Undang-undang Nomor 23 Tahun 2002 dan Qanun Nomor 6 Tahun 2014 tentang Hukum Jinayat dan analisis terhadap Putusan Mahkamah Syar'iyah Langsa Nomor 05/JN/2016/MS. Metode yang digunakan dalam penelitian ini adalah analisis isi atau content analysis, yang menggunakan data sekunder yaitu penelitian yang bersifat pembahasan mendalam terhadap isi suatu dokumen tertulis baik dari buku maupun tulisan ilmiah lainnya yang relevan dengan pengaturan hukum pidana. Namun dalam penelitian ini juga menggunakan metode sosiologis/empiris dengan melakukan wawancara kepada salah satu hakim Mahkamah Syar'iyah. Kesimpulan tulisan adalah bahwa terdapat perbedaan sanksi pidana dalam Undang-undang Nomor 35 Tahun 2014 dengan Qanun Nomor 6 Tahun 2014. Sanksi pidana dalam Qanun Nomor 6 Tahun 2014 lebih rendah dibandingkan dalam Undangundang Nomor 35 Tahun 2014 yang merupakan payung hukum dari upaya perlindungan terhadap anak.
\end{abstract}

Kata kunci: sanksi pidana, ayah, tindak pidana pemerkosaan

\begin{abstract}
The purpose of this study was to determine the sanction of criminal law to the father as the perpetrator of rape according to Law No. 35 of 2014 on the Amendment of Act No. 23 of 2002 and Qanun No. 6 of 2014 on the Law Jinayat and analysis of Court Decision shar ' Yeah Langsa No. 05 / JN / 2016 / MS. The method used in this research is the analysis of the content or the content analysis, which uses secondary data research that is in-depth discussion of the content of a written document from the book and other scientific papers relevant to criminal law arrangements. But in this study also used the sociological method / empirical to do an interview to one Syar'iyah Court judges. The conclusion is that there is a difference writings criminal sanctions in Law No. 35 of 2014, with Qanun No. 6 of 2014. The criminal sanction in Qanun No. 6 of 2014 was lower than in Act No. 35 of 2014 which is the legal umbrella of safeguards against child.
\end{abstract}

\section{Keyword : sanction of criminal, father, the perpetrator of rape}

\section{Pendahuluan}

Kejahatan sebagai suatu fenomena sosial merupakan bagian dari keseluruhan proses-proses sejarah peradaban manusia, dimana interaksi yang dilakukan oleh manusia memungkinkan terjadinya ketersinggungan kepentingan dengan manusia lainnya. Kejahatan dalam masyarakat (crime in society) tetap dipengaruhi oleh berbagai aspek kehidupan masyarakat seperti : politik, ekonomi, sosial, budaya dan sebagainya. Indonesia memiliki kompleksitas persoalan anak yang hingga saat ini belum terselesaikan secara menyeluruh dan komprehensif.

Peningkatan kekerasaan seksualterhadap anak terjadi sepanjang 5 tahun terakhir. Berdasar data yang dihimpun Pusat Data dan Informasi (Pusdatin) Komnas 
Anak, dalam kurun waktu 2010-2015.Samsul Ridwan mengatakan jumlah aduan pada 2010 sebanyak 2.046, di mana 42\% di antaranya merupakan kejahatan seksual. Pada 2011 menjadi 2.467 kasus, yang $52 \%$ kejahatan seksual.Sementara pada 2012, ada 2.637 aduan yang $62 \%$ kekerasan seksual.Meningkat lagi di 2013 menjadi 2.676 kasus, di mana 54\% didominasi kejahatan seksual. Kemudian pada 2014 sebanyak 2.737 kasus dengan 52\% kekerasan seksual. Melihat 2015, terjadi peningkatan pengaduan sangat tajam, ada 2.898 kasus dimana 59,30\% kekerasan seksual dan sisanya kekerasan lainnya.62 \% kekerasan terhadap anak terjadi di lingkungan terdekat keluarga dan lingkungan sekolah, selebihnya 38\% di ruang publik. Bukan hanya itu, predator atau pelaku kejahatan terhadap anak juga dilakukan orang terdekat seperti ayah kandung, ayah tiri, abang, keluarga terdekat, guru, tetangga, bahkan penjaga sekolah. ${ }^{1}$

Data tersebut sungguh bertolak belakang dengan semangat Indonesia dalam upaya perlindungan terhadap anak. Beberapa instrumen hukum yang dimiliki Indonesia menunjukkan bahwa Indonesia telah lama memberikan perhatian terhadap upaya perlindungan terhadap anak, Seperti Pasal 28B UUD NRI 1945, Undang-Undang Nomor 4 Tahun 1979 tentang Kesejahteraan Anak, Ratifikasi Konvensi Hak Anak melalui Keputusan Presiden Nomor 36 Tahun 1990, Undang-Undang Nomor 39 Tahun 1999 tentang Hak Asasi Manusia, Undang-Undang Nomor 23 Tahun 2002 tantang Perlindungan Anak, Undang-Undang Nomor 12 Tahun 2006 tentang Kewarganegaraan, UndangUndang Nomor 35 Tahun 2014 tentang Perubahan Undang-Undang Nomor 23 Tahun 2002 tentang Perlindungan Anak serta dengan dibentuknya suatu lembaga

1 http://news.liputan6.com/read/23960 14/komnas-pa-2015-kekerasan-anak-tertinggiselama-5-tahun-terakhir. Diakses Pada pukul 13.00 WIB. Tanggal 22 Oktober 2016. independen yang kedudukannya sejajar dengan komisi lainnya yaitu KPAI (Komisi Perlindungan Anak Indonesia). Semua hal tersebut membuktikan keperdulian Indonesia terhadap komitmen penyelenggaraan perlindungan terhadap anak.

Indonesia memasuki periode keterpurukan hukum dimana kejahatan terhadap anak meningkat tajam. Situasi ini membawa Indonesia dalam Periode Darurat Kekerasan terhadap Anak. Padahal Anakanak adalah bagian dari generasi muda sebagai pemegang tongkat estafet kepemimpinanbangsa yang akan datang. Rizzini, seorang psikolog menyatakan "Anakanak adalah awal sebuah peradaban, kemusnahan/kerusakan anak-anak adalah, kemusnahan sebuah peradaban." 2 pendapat Rizzini menjelaskan bahwa baik buruknya kualitas anak-anak yang dimiliki suatu bangsa akan berdampak pada keberlangsungan dan masa depan bangsa tersebut. Melihat peran strategis tersebut sudah seharusnya pemerintah dan seluruh elemen masyarakat memberikan perhatian secara serius untuk membentuk anak-anak yang cerdas, pintar, berakhlak baik serta melindungi anak dari kekerasan, diskriminasi yang berakibat pada terganggunya psikologis anak.

Tindak pidana pemerkosaan adalah salah satu tindak pidana kekerasan seksual baik dilakukan terhadap anak-anak atau orang dewasa. Pemerkosaan yang dilakukan terhadap anak menimbulkan dampak yang sangat kompleks, dikarenakan tidak hanya kerugian materiil yang dialami korban namun kerugian inmateriil yang berdampak panjang dan merusak masa depan anak. Sesuatu yang justru sangat mengenaskan adalah tindak pidana pemerkosaan yang

2M.Ghufron H Kordi K, Durhaka Kepada Anak (Refleksi mengenai Hak\&Perlindungan Anak), (Yogyakarta: Pustaka Baru Press), 2015, hal 2. 
dilakukan oleh ayah terhadap anak kandungnya.

Di Langsa telah terjadi tindak pidana pemerkosaan yang dilakukan oleh ayah kandung (AS) terhadap anak perempuannya Bunga (bukan nama sebenarnya). Perbuatan tercela itu terjadi sebanyak 2 (dua) kali yaitu pada bulan oktober 2015 dan 5 November 2015. Berdasarkan perbuatan terdakwa maka Mahkamah Syar'iyah Langsa dalam Putusan Nomor 05/JN/2016/MS.Lgs memutuskan menghukum terdakwa dengan pidana penjara selama 180 (seratus delapan puluh bulan) atau 15 (lima belas) tahun. Berdasarkan putusan tersebut terdakwa mengajukan banding. Mahkamah Syar'iyah Aceh dalam Putusan Nomor 06/JN/2016/MS.Aceh memutuskan Menguatkan Putusan Mahkamah Syar'iyah Langsa. Selanjutnya terdakwa mengajukan kasasi dan Mahkamah Agung dalam Putusan Nomor 03/K/Ag/JN/2016 memutuskan Menolak permohonan kasasi dari terdakwa.

Pengaturan mengenai tindak pidana pemerkosaan yang dilakukan terhadap anak diatur dalam Undang-Undang Nomor 35 Tahun 2014 tentang Perlindungan Anak. Tetapi khusus untuk provinsi Aceh dengan pemberlakuan syaria'at Islam maka sanksi hukum terhadap tindak pidana pemerkosaan diatur dalam QanunNomor 6 Tahun 2014 tentang Hukum Jinayat. Perlakuan ini sesuai dengan asas Lex specialis derogat legi generalis. Asas tersebut menyatakan bahwa hukum yang bersifat khusus (lex specialis) mengesampingkan hukum yang bersifat umum (lex generalis).

Terdapat perbedaan sanksi pidana bagi tindak pidana pemerkosaan yang diatur dalam Undang-Undang Nomor 35 Tahun 2014 dengan Qanun Nomor 6 Tahun 2014. Berdasarkan uraian kasus diatas penulis tertarik untuk membahas tulisan ini dalam beberapa permasalahan yaitubagaimana sanksi hukum pidana terhadap ayah sebagai pelaku tindak pidana pemerkosaan menurut Undang-Undang Nomor 35 Tahun 2014 tentang Perubahan Atas Undang-Undang Nomor 23 Tahun 2002 dan Qanun Nomor 6 Tahun 2014 tentang Hukum Jinayat ? Bagaimana analisis terhadap Putusan Mahkamah Syar'iyah Langsa Nomor 05/JN/2016/MS.Lgs?

Metode yang digunakan dalam penelitian ini adalah analisis isi atau content analysis $^{3}$,yangmenggunakan data sekunder yaitu penelitian yang bersifat pembahasan mendalam terhadap isi suatu dokumen tertulis baik dari buku maupun tulisan ilmiah lainnya yang relevandenganpengaturan hukum pidana. Namun dalam penelitian ini juga menggunakan metode sosiologis/empiris dengan melakukan wawancara kepada salah satu hakim Mahkamah Syar'iyah.

\section{Perumusan Masalah}

Yang menjadi Rumusan Masalah pada penelitian ini adalah:

1. Bagaimana kajian pengertian tindak pidana pemerkosaan berdasarkan Hukum

Nasional dan Hukum Syariat Islam?

2. Bagaimana sanksi pidana terhadap ayah sebagai pelaku tindak pidana pemerkosaan menurut Hukum Nasional?

3. Bagaimana sanksi pidana terhadap ayah sebagai pelaku tindak pidana pemerkosaan menurut Hukum Syariat Islam (Qanun)?

\section{Metode Penelitian}

\section{A. Jenis dan Sifat Penelitian}

Penelitian ini jenisnya penelitian yuridis normatif. Pendekatan yuridis normatif, yakni penelitian yang difokuskan untuk mengkaji penerapan atau kaidahkaidah atau norma-norma dalam hukum positif. ${ }^{4}$ Bentuk dari hasil penelitian ini akan dituangkan secara deskriptif. Suatu penelitian deskriptif, dimaksudkan untuk memberikan gambaran yang seteliti mungkin manusia, keadaan atau gejala-gejala

3 R. Babbie., Loc. Cit

${ }^{4}$ Johnny Ibrahim, Teori dan Metodologi

Penelitian Hukum Normatif, (Malang: Banyumedia Publishing), 2008, hal 295. 
lainnya. 5 Yang dalam hal ini dibatasi mengenai sanksi pidana terhadap seorang ayah yang melakukan tindak pidana pemerkosaan menurut Hukum Nasional dan Hukum Syariat Islam (Qanun).

Penelitian bersifat deskriptif analitis yaitu merupakan penelitian yang bertujuan menggambarkan secara cermat karakteristik dari fakta-fakta (individu, kelompok atau keadaan) dan untuk menentukan frekuensi sesuatu terjadi. ${ }^{6}$ Analisis yang dimaksud berdasarkan gambaran, fakta yang diperoleh akan dilakukan analisis secara cermat untuk menjawab penelitian. ${ }^{7}$

\section{B. Sumber Data}

Dalam penyusunan yang digunakan dalam penulisan ini, data dan sumber data yang digunakan adalah :

1. Bahan Hukum Primer, yaitu bahan hukum yang terdiri dari Kitab UndangUndang Hukum Pidana (KUHP), Undang-Undang No. 35 Tahun 2014 tentang Perlindungan Anak. Qanun No. 6 Tahun 2014 Tentang Hukum JInayat, dan Peraturan Perundang-Undangan yang berkaitan dengan Perlindungan Anak.

2. Bahan hukum sekunder, yaitu berupa bahan yang memberikan penjelasan terhadap bahan hukum primer, yaitu hasil karya para ahli hukum berupa buku-buku, pendapat-pendapat para sarjana yang berhubungan dengan penelitian ini.

3. Bahan Hukum tersier atau bahan hukum penunjang, yaitu bahan hukum yang memberikan petunjuk atau penjelasan bermakna terhadap bahan hukum primer dan/atau bahan hukum sekunder, yaitu Kamus Hukum, dan lain-lain.

\section{Metode Pengumpulan Data}

${ }^{5}$ Soejono Soekanto, Pengantar Penelitian Hukum, (Jakarta: UI Press), 2006, hal 295.

${ }^{6}$ Rianto Adi, Metode Penelitian Sosial dan Hukum, (Jakarta: Granit), 2000, hal 58.

7 Sunaryati Hartono, Penelitian Hukum Indonesia Pada Akhir ke-20, (Bandung: Alumni), 1994, hal, 101
Teknik Pengumpulan Data yang dipergunakan di dalam penelitian ini adalah dengan cara "Penelitian Kepustakaan" (Library Research) yaitu penelitian yang dilakukan dengan cara pengumpulan Literatur dengan sumber data berupa bahan hukum primer dan ataupun bahan hukum sekunder yang ada hubungan dengan permasalahan yang dibahas dalam penelitian ini.

\section{Analisis Data}

Di dalam penulisan ini yang termasuk ke dalam tipe penelitian hukum normatif, pengelolaan data pada hakikatnya merupakan kegiatan untuk melakukan analisis data terhadap permasalahan yang dibahas. Hal ini dilakukan dengan menganalisa bahan-bahan yang diperoleh dari peraturan produk perundang-undangan, buku, dan karya ilmiah serta bahan dari internet yang berkaitan erat dengan "Kajian Yuridis Sanksi Pidana Terhadap Ayah Sebagai Tindak Pelaku Pemerkosaan Menurut Qanun Nomor 6 Tahun 2014" yang kemudian dianalisa secara induktif kualitatif.

\section{Hasil dan Pembahasan \\ A. Pengertian Tindak Pidana Pemerkosaan}

Istilah tindak pidana berasal dari istilah yang dikenal dari hukum pidana Belanda yaitu "Strafbaar feit" istilah ini terdapat dalam Wetboek van Strafrecht Belanda, tetapi tidak ada penjelasan resmi mengenai apa yang dimaksud dengan Strafbaar feit. ${ }^{8}$ Strafbaar feit adalah kelakuan (handeling) yang diancam dengan pidana, yang bersifat melawan hukum, berhubungan dengan kesalahan dan dilakukan oleh orang yang bertanggungjawab.

Vos merumuskan definisi Strafbaar feit adalah een menselijke gedraging, waarop

${ }^{8}$ Adami Chazawi, Pelajaran Hukum Pidana, (Jakarta: Raja Grafindo Persada),, 2002, hal 67. 
door wet straf is gesteld (perbuatan pidana adalah suatu kelakuan manusia yang diancam pidana oleh peraturan perundangundangan). ${ }^{9}$ Sedangkan Moeljatno memberi definisi perbuatan pidana sebagai "perbuatan yang dilarang dalam undangundang dan diancam dengan pidana barangsiapa melanggar larangan itu."10

Hazewinkel Suringa seperti dikutip oleh Lamintang mengartikan Strafbaar feit sebagai suatu perilaku manusia yang pada suatu saat tertentu telah ditolak dalam sesuatu pergaulan hidup tertentu dan dianggap sebagai perilaku yang harus ditiadakan oleh hukum pidana dengan menggunakan saran-sarana yang bersifat memaksa yang terdapat di dalamnya. Pompe menyebutkan bahwa Strafbaar feit secara teoritis dapat dirumuskan sebagai suatu pelanggaran norma (gangguan terhadap tata tertib hukum) yang dengan sengaja maupun tidak sengaja telah dilakukan oleh seorang pelaku, dimana penjatuhan hukuman terhadap pelaku tersebut adalah perlu demi terpeliharanya tertib hukum dan terjaminnya kepentingan umum. ${ }^{11}$

Berdasarkan pengertian diatas tindak pidana atau perbuatan pidana diartikan sebagai perbuatan yang dilarang oleh undang-undang dan memiliki sanksi bagi yang melanggarnya. Dalam definisi yang dirumuskan Suringa menyinggung mengenai kesalahan dimana kesalahan itu sendiri berkaitan dengan pertanggungjawaban pidana.

Kekerasan seksual adalah semua bentuk ancaman dan pemaksaan seksual. Dengan kata lain kekerasan seksual adalah kontak seksual yang tidak dikehendaki oleh

${ }^{9}$ Bambang Poernomo, Asas-asas Hukum Pidana, (Jakarta: Penerbit Balai Aksara), 1993, hal 126.

10 Eddy O.S. Hiariej, Prinsip-prinsip Hukum Pidana, (Yogyakarta: Cahaya Atma Pusaka), 2014, hal 91.

${ }^{11}$ Lamintang, Dasar-dasar Hukum Pidana Indonesia, (Bandung: PT Citra Adiyta Bakti), 1997, hal 181-182. salah satu pihak. Intinya kekerasan seksual terletak pada ancaman (verbal) dan pemaksaan (tindakan). 12 Dalam Kitab Undang-Undang Hukum Pidana (KUHP) pengertian mengenai kekerasan seksual dapat ditemui dalam Pasal 285 dan Pasal 289. Dalam Pasal 285 ditentukan bahwa barang siapa dengan kekrasan atau ancaman kekerasan memaksa perempuan yang bukan istrinya berhubungan seksual dengan dia, dihukum, karena memperkosa dengan hukuman penjara selam-lamanya 12 tahun.

Sedangkan dalam Pasal 289 KUHP disebutkan barang siapa dengan kekerasan atau ancaman kekerasan memaksa seseorang melakukan atau membiarkan melakukan pada dirinya perbuatan cabul, dihukum karena merusakkan kesopanan dengan hukuman penjara selama-lamanya sembilan tahun.

Menurut R.Soesilo yang dimaksud dengan perbuatan cabul, sebagaimana disebutkan dalam Pasal 289 KUHP, adalah segala perbuatan yang melanggar ksesusilaan (kesopanan) atau perbuatan keji yang semua ada kaitannya dengan nafsu birahi kelamin, misalnya : cium-cium, meraba-raba anggota kemaluan, merabaraba buah dada, dan semua bentuk perbuatan cabul. ${ }^{13}$

Ancaman adalah tindakan menakutnakuti. Tujuan dari tindakan ini adalah agar pihak lain bertindak sesuai dengan keinginan pihak yang menakut-nakuti. Ketika orang dewasa mangancam anak untuk melakukan tindakan sesuai dengan keinginannya, apabila anak ketakutan dan kemudian mematuhi yang diperintah orang dewasa, maka ancaman tersebut akan terealisasi

12 M.Irsyad Thamrin dan M.Farid, Panduan Bantuan Hukum Bagi Paralegal, (Yogyakarta: Lembaga Bantuan Hukum Yogyakarta Bekerja Sama dengan TIFA Fondation), 2010, hal 518

${ }^{13}$ R.Soesilo, Kitab Undang-Undang Hukum Pidana (KUHP) serta Komentar-Komentarnya Lengkap Pasal Demi Pasal, (Bogor:Politeia), 1996, hal 212. 
dalam bentuk tindakan. Memaksa adalah perintah dari suatu pihak agar pihak lain mengerjakan sesuatu yang diinginkannya. Walaupun pihak lain tidak mau mengerjakannya, namun pihak yang memberikan perintah mengharuskan pihak tersebut mengerjakannya. ${ }^{14}$

Memperkosa adalah memasukkan secara paksa penis ke dalam vagina atau dubur. Jadi istilah memperkosa ini memberika kandungan yang sama dengan memaksa, yakni sama-sama bentuk dari tindakan hanya bedanya tindakan memaksa belum tentu berbentuk persetubuhan, sedangkan memperkosa sudah pasti berbentuk persetubuhan terlepas persetubuhan itu dilakukan antar orang dewasa atau dengan anak-anak, 15 Kecendrungan masyarakat untuk melampiaskan rasa kemarahan dan kebenciannya terhadap pelaku tindka pidana ini rupanya terbatas hanya pada tindak pidana kovensional seperti pencurian, perampokan (pencurian dengan kekerasan), penipuan, dan penggelapan tetapi tidak pada tindak pidana yang dilakukan oleh orangorang yang memiliki kedudukan atau status sosial terhormat seperti "kejahatan berdasi" atau "kejahatan kerah putih".

Berdasarkan pelakunya terdapat empat jenis pemerkosaan yaitu sebagai berikut :

1. Perkosaan yang dilakukan oleh orang yang dikenal

Yaitu perkosaan yang dilakukan oleh teman atau anggota keluarga.

2. Perkosaan oleh pacar (dating rape) Yaitu perkosaan yang terjadi ketika korban sedang berkencan dengan pacarnya seringkali diawali cumbuan yang akhirnya terjadi pemaksaan hubungan seks.

${ }^{14}$ Ismantoro Dwi Yuwono, Penerapan Hukum Dalam Kasus Kekerasan Seskual Terhadap Anak, (Jakarta: PT Buku Seru), 2015, hal 4. ${ }^{15}$ Ibid
3. Perkosaan dalam perkawinan (marital rape)

Yaitu perkosaan yang biasa terjadi pada istri yang ketergantungan sosial ekonomi pada suami, berupa pemaksaan hubungan yang tidak dikehendaki oleh pihak istri.

4. Perkosaan oleh orang asing Yaitu perkosaan yang seringkali disertai dengan kejahatan lainnya seperti perampokan, pencurian, penganiayaan ataupun pembunuhan. ${ }^{16}$

\section{Qanun Jinayat}

Qanun secara etimologis, berasal dari bahasa yunani yang masuk menjadi bahasa Arab yang melalui bahasa Siryani yang berarti alat pengukur. Dalam bahasa Inggris qanun disebut canon, yang antara lain sinonim artinya dengan peraturan (regulation, rule, atau ordinance), hukum (law), norma (norm), undang-undang (statute atau code), dan peraturan dasar (basic rule). Dalam konteks Indonesia, istilah 'qanun' digunakan tidak hanya untuk hukum yang berkaitan dengan masyarakat, tapi juga untuk hukum yang bertalian dengan masalah ibadah seperti zakat dan haji. Perlu digaris bawahi, di samping dapat berarti hukum atau hal-hal yang berisi hukum, qanun juga dapat digunakan istilah bagi pendaftaran dan list (daftar), rekaman pajak tanah (register and list recording land taxes) ${ }^{17}$.

Berdasarkan Undang-Undang No. 11 Tahun 2006 tentang Pemerintahan Aceh, Pemerintah Aceh diberikan beberapa kewenangan istimewa dalam mengurus daerahnya.Salah satu kewenangan yang dimiliki oleh Pemerintah Aceh adalah penerapan nilai-nilai syari'at Islam kepada masyarakat setempat yang diatur

${ }^{16} \mathrm{http}: / /$ situs.kesrepro.info/gerdervaw/ materi/perkosaan

${ }^{17}$ Ahmad Sukardja, dan Mujar IbnuSyarif, Tiga Kategori Hukum: Syariat, Fikih, \& Qanun, (Jakarta: SinarGrafika), 2012, hal 120. 
berdasarkan Qanun. Qanun sendiri merupakan peraturan perundang-undangan sejenis peraturan daerah provinsi/kabupaten/kota yang mengatur penyelenggaraan pemerintahan dan kehidupan masyarakat Aceh.

Kata jinayah merupakan bentuk verbal noun (masdar) dari kata jana. Secara etimologi, kata jana berarti berbuat dosa atau salah, sedangkan jinayah diartikan perbuatan dosa atau perbuatan salah. Orang yang berbuat salah disebut jani dan orang yang dikenai perbuatan atau korban disebut mujna'alaih. Kata jinayah dalam istilah hukum sering disebut dengan delik atau tindak pidana. ${ }^{18}$

Qanun Nomor 6 Tahun 2014 Tentang Hukum Jinayat mulai diberlakukan di Aceh pada 23 Oktober 2015. Pemberlakukan qanun ini mulai berlaku satu tahun setelah diundangkan pada 23 Oktober 2014 lalu. Qanun Jinayat merupakan kesatuan hukum pidana yang berlaku bagi masyarakat Aceh yang dibentuk berdasarkan nilai-nilai syari'at Islam. Qanun Jinayat mengatur tentang Jarimah (perbuatan yang dilarang oleh syari'at Islam), pelaku jarimah, dan uqubat (hukuman yang dapat dijatuhkan oleh hakim terhadap pelaku jarimah).

Cita-cita mewujudkan syari'at Islam tersebut diwujudkan dalam aturan hukum daerah yang disebut dengan Qanun. Salah satu unsur dari pengaturan Syari'at Islam dalam aturan qanun adalah adanya unsur pidana Islam (jinayah), yang bertujuan menimbulkan aspek "jera" bagi para pelaku pelanggar Syari'at Islam. Selain itu juga, dengan ditetapkannya lembaga peradilan yang berwenang mengadili dan menghukum pelaku pelanggar Syari;at Islam, yaitu Mahkamah Syar'iyah, menjadikan gambaran bahwa setiap unsur dalam pemerintahan

18Zulkarnain Lubis dan Bakti Ritonga, Dasar-dasar Hukum Acara Jinayah, (Prenadamedia Group), 2016, hal 2.
Aceh berupaya untuk menjaga dan melestarikan nilai-nilai Syari'at Islam. ${ }^{19}$

\section{B. Sanksi Pidana Terhadap Ayah Sebagai Pelaku Tindak Pidana Pemerkosaan Menurut Undang-Undang Nomor 35 Tahun 2014 tentang Perubahan Atas Undang-Undang Nomor 23 Tahun 2002.}

Anak sebagai makhluk Tuhan Yang Maha Esa dan mahluk sosial, sejak dalam kandungan hingga berusia 18 (delapan belas) tahun hak-hak yang dilindungi oleh hukum, dimana hak-hak tersebut mengakomodir karakteristik/ciri khas seorang anak. Prinsip-prinsip umum perlindungan anak yaitu nondiskriminasi, kepentingan terbaik anak, keberlangsungan hidup dan tumbuh kembang, dan menghargai partisipasi anak.

Untuk melaksanakan upaya perlindungan terhadap kesejahteraan anak dan memberikan jaminan terhadap pemenuhan hak-haknya tanpa adanya perlakuan diskriminatif, maka negara telah memberikan payung hukum yakni UndangUndang Nomor 23 Tahun 2002 tentang Perlindungan Anak. Namun seiring berjalannya waktu, pada kenyataannya undang-undang tersebut dirasa belum dapat berjalan secara efektif karena masih adanya tumpang tindih antar peraturan perundangundangan sektoral terkait dengan definisi anak, di sisi lainmeningkatnya kejahatan terhadap anak di tengah-tengah masyarakat, salah satunya adalah kejahatan seksual yang saat ini banyak dilakukan oleh orang-orang dekat sang anak, serta belum terakomodirnya perlindungan hukum terhadap anak penyandang disabilitas.

${ }^{19}$ fahum.unsam.ac.id/2016/09/urgensipenetapan-hukum-jinayah-dan-acara-jinayah-diaceh-suatu-wujud-mengembalikan-moralitasmasyarakat-aceh.html, diakses pada tanggal 27 Oktober 2016 . 
Sehingga, berdasarkan paradigma tersebut maka Undang-Undang Nomor 23 Tahun 2002 tentang Perlindungan Anak yang saat ini sudah berlaku \pm (kurang lebih) 12 (dua belas) tahun akhirnya diubah dengan Undang-Undang Nomor 35 Tahun 2014 tentang Perubahan Atas Undang-Undang Nomor 23 Tahun 2002 tentang Perlindungan Anak

Undang-Undang Nomor 35 Tahun 2014 mempertegas tentang perlunya pemberatan sanksi pidana dan denda bagi pelaku kejahatan terhadap anak terutama kepada kejahatan seksual yang bertujuan untuk memberikan efek jera, serta mendorong adanya langkah konkrit untuk memulihkan kembali fisik, psikis dan sosial anak. Hal tersebut perlu dilakukan untuk mengantisipasi anak (korban kejahatan) dikemudian hari tidak menjadi pelaku kejahatan yang sama. Karena berdasarkan fakta yang terungkap pada saat pelaku kejahatan terhadap anak (terutama pelaku kejahatan seksual) diperiksa di persidangan, ternyata sang pelaku dulunya juga pernah mengalami (pelecehan seksual) sewaktu sang pelakumasih berusia anak, sehinggasang pelaku terobsesi untuk melakukan hal yangsama sebagaimana yang pernah dialami.

Undang-Undang 35 Tahun 2014 melarang perbuatan kejahatan seksual terhadap anak, Pasal 76D menyebutkan: "setiap orang dilarang melakukan kekerasan atau ancaman kekerasan memaksa anak melakukan persetubuhan dengannya atau dengan orang lain". Selanjutnya Pasal 76E menyebutkan: "setiap orang dilarang melakukan kekerasan atau ancaman kekerasan, memaksa, melakukan tipu muslihat, melakukan serangkaian kebohongan, atau membujuk aak untuk melakukan atau membiarkan dilakukan perbuatan cabul."

Sanksi pidana terhadap kejahatan seksual tersebut yaitu Pasal 76D tindak pidana pemerkosaan diatur dalam Pasal 81 yang berbunyi:

1) Setiap orang yang melanggar ketentuan sebagaimana dimaksud dalam Pasal 76D dipidana dengan pidana penjara paling singkat 5 (lima) tahun dan paling lama 15 (lima belas) tahun dan denda paling banyak Rp5.000.000.000,00 (lima miliar rupiah).

2) Ketentuan pidana sebagaimana dimaksud pada ayat (1) berlaku pula bagi Setiap Orang yang dengan sengaja melakukan tipu muslihat, serangkaian kebohongan, atau membujuk Anak melakukan persetubuhan dengannya atau dengan orang lain.

3) Dalam hal tindak pidana sebagaimana dimaksud pada ayat (1) dilakukan oleh Orang Tua, Wali, pengasuh Anak, pendidik, atau tenaga kependidikan, maka pidananya ditambah $1 / 3$ (sepertiga) dari ancaman pidana sebagaimana dimaksud pada ayat (1).

Kemudian sanksi pidana terhadap Pasal 76E tindak pidana pencabulan diatur dalam Pasal 82 yang berbunyi:

1) Setiap orang yang melanggar ketentuan sebagaimana dimaksud dalam Pasal 76E dipidana dengan pidana penjara paling singkat 5 (lima) tahun dan paling lama 15 (lima belas) tahun dan denda paling banyak Rp5.000.000.000,00 (lima miliar rupiah).

2) Dalam hal tindak pidana sebagaimana dimaksud pada ayat (1) dilakukan oleh Orang Tua, Wali, pengasuh Anak, pendidik, atau tenaga kependidikan, maka pidananya ditambah $1 / 3$ (sepertiga) dari ancaman pidana sebagaimana dimaksud pada ayat (1)

Berdasarkan uraian sanksi pidana
diatas menjelaskan bahwa adanya
pemberatan sanksi pidana bagi orangtua,
wali, pengasuh anak, pendidik atau tenaga
kependidikan yang melakukan kejahatan
seksual terhadap anak, baik tindak pidana
pemerkosaan maupun pencabulan.
Pemberatan tersebut adalah $1 / 3$ dari
ancaman pidana. Sehingga ancaman


maksimal menjadi 20 (dua puluh) tahun penjara.

\section{Sanksi Pidana Terhadap Ayah Sebagai Pelaku Tindak Pidana Pemerkosaan Menurut Qanun Nomor 6 Tahun 2014 tentang Hukum Jinayat.} adalah:

Pemerkosaan dalam qanun jinayat

Pemerkosaan adalah hubungan seksual terhadap faraj atau dubur orang lain sebagai korban dengan zakar pelaku atau benda lainnya yang digunakan pelaku atau terhadap faraj atau zakar korban dengan mulut pelaku atau terhadap mulut korban dengan zakar pelaku, dengan kekerasan atau paksaan atau ancaman terhafap korban. ${ }^{20}$

Qanun jinayat mengatur mengenai sanksi pidana terhadap jarimahpemerkosaan dalam Pasal 48 sampai dengan Pasal 56. Namun dalam tulisan ini pasal yang dibahas adalah Pasal 48, 49 dan Pasal 50, yang masing-masing berbunyi :

Pasal 48

Setiap orang yang dengan sengaja melakukan jarimah pemerkosaan diancam dengan 'uqubat Ta'zir cambuk paling sedikit 125 (seratus dua puluh lima) kali, paling banyak 175 (seratus tujuh puluh lima) kali atau denda paling sedikit 1.250 (seribu dua ratus lima puluh) gram emas murni, palin banyak 1.750 (seribu tujuh ratus lima puluh) gram emas murni, atau penjara paling singkat 125 (seratus dua puluh lima) bulan, paling lama 175 (seratus tujuh puluh lima) bulan.

Pasal 49

Setiap orang yang dengan sengaja melakukan jarimah pemerkosaan terhadap orang yang memiliki hubungan mahram

20 Pasal 1 Angka 30 Undang-Undang Nomor 6 Tahun 2014 tentang Hukum Jinayat. dengannya, diancam dengan 'uqubat Ta'zir cambuk paling sedikit 150 (seratus lima puluh) kali, paling banyak 200 (dua ratus) kali atau denda paling sedikit 1.500 (seribu lima ratus) gram emas murni, paling banyak 2.000 (dua ribu), gram emas murni atau penjara paling singkat 150 (seratus lima puluh) bulan, paling lama 200 (dua ratus) bulan.

\section{Pasal 50}

Setiap orang yang dengan sengaja melakukan jarimah pemerkosaan sebagaimana dimaksud dalam Pasal 48 terhadap anak-diancam dengan 'uqubat Ta'zir cambuk paling sedikit 150 (seratus lima puluh) kali, paling banyak 200 (dua ratus) kali atau denda paling sedikit 1.500 (seribu lima ratus) gram emas murni, paling banyak 2.000 (dua ribu) gram emas murni atau penjara paling singkat 150 (seratus lima puluh) bulan, paling lama 200 (dua ratus) bulan.

Pengertian mahram menurut qanun jinayat adalah:

Mahram adalah orang yang haram dinikahi selama-lamanya yakni orang tua kandung dan seterusnya ke atas, orang tua tiri, anak dan seterusnya ke bawah, anak tiri dari istri yang telah disetubuhi, saudara (kandung, seayah dan seibu), sauara susuan, ayah dan ibu susuan, saudara ayah, saudara ibu, anak saudara, mertua (laki-laki dan perempuan), menantu (laki-laki dan perempuan). ${ }^{21}$

Sedangkan anak adalah "orang yang belum mencapai umur 18 (delapan belas) tahun dan belum menikah."22

${ }^{21}$ Pasal 1 Angka 25 Undang-Undang Nomor 6 Tahun 2014 tentang Hukum Jinayat

22 Pasal 1 Angka 40 Undang-Undang Nomor 6 Tahun 2014 tentang Hukum Jinayat 
Dari ketiga pasal diatas terdapat perbedaan pada unsur korban pemerkosaan. Dalam Pasal 48, korban pemerkosaan adalah dewasa dan orang lain (bukan mahram), dalam Pasal 49, korban pemerkosaan adalah mahram, baik dewasa maupun anak, termasuk anak kandung atau tiri yang berumur belum 18 tahun dan belum menikah masuk dalam kategori unsur pasal ini. sedangkan dalam Pasal 50, korban pemerkosaan adalah anak-anak yang belum 18 tahun dan belum menikah serta bukan mahram pelaku.

Perbedaan lainnya terletak pada sanksi hukum yaitu sanksi pidana dalam Pasal 48 lebih rendah 25 kali cambukan, 250 gram emas murni dan 25 bulan penjara. Dibandingkan dengan Pasal 49 dan 50. Khusus bagi pemerkosaan terhadap anak, dua Pasal yang dapat dikenakan adalah Pasal 49 dan Pasal 50. Dimana ancaman maksimal kedua pasal tersebut adalah 200 kali cambukan, 2.000 gram emas murni, 200 bulan (16 tahun, 6 bulan).

Sedangkan perbedaan sanksi pidana antara Undang-Undang Nomor 35 Tahun 2014 dengan Qanun Nomor 6 Tahun 2014 yaitu:

1. Sanksi pidana maksimal dalam UndangUndang Nomor 35 Tahun 2014 bagi pelaku pemerkosaan terhadap anak yang dilakukan oleh Orang Tua, Wali, pengasuh Anak, pendidik, atau tenaga kependidikandiperberat $1 / 3$ menjadi yaitu 20 (dua puluh tahun) penjara dan denda Rp5.000.000.000,00 (lima miliar rupiah).

Sedangkan dalam qanun

hukumjinayat sanksi pidana cambuk maksimal 200 kali, denda 2.000 gram emas murni (sampai dengan tulisan ini diturunkan, emas murni per gram adalah Rp. $552.000,-\quad \times 2.000$ gram emas = Rp.1.104.000.000) sedangkan sanksi maksimal penjara adalah 200 bulan (16 tahun, 6 bulan).

Berdasarkan uraian diatas dapat terlihat bahwa sanksi hukum dalam Undang-
Undang Nomor 35 Tahun 2014 lebih berat dari qanun Nomor 6 Tahun 2014 tentang hukum jinayat

2. Pelaku pemerkosaan terhadap anak yang dalam UndangUndang Nomor 35 Tahun 2014 yang dikenakan pemberatan, adalah pelaku yang disebutkan secara konkrit yaitu Orang Tua, Wali, pengasuh Anak, pendidik, atau tenaga kependidikan.

Sedangkan pelaku pemerkosaan terhadap anak dalam qanun hukumjinayat Nomor 6 Tahun 2014, tidak ada pasal pemberatan bagi pelaku pemerkosaan dalam kategori seperti dalam Undang-Undang Nomor 35 Tahun 2014 yaitu Orang Tua, Wali, pengasuh Anak, pendidik, atau tenaga kependidikan. Sanksi pidana bagi pemerkosa anak dalam Pasal 49 dan Pasal 50 memiliki ancaman hukuman yang sama.

\section{Analisis Terhadap Putusan Mahkamah Syar'iyah Langsa Nomor 05/JN/2016/MS.Lgs}

Kronologis kasus secara singkat:

Pada hari dan tanggal yang tidak diingat lagi yaitu bulan Oktober 2015 pukul 04.00 wib dan Pada hari Kamis tanggal 5 November 2015 pukul 04.30 wib AS telah melakukan jarimah pemerkosaan terhadap mahram yaitu Bunga (13 tahun) sebagai korban. Bermula bulan Oktober 2015 terdakwa mendapat kabar bahwa anak kandungnya yaitu Bunga sudah disetubuhi oleh ayah tirinya yang bernama Dedi. Mendengar hal tersebut kemudian terdakwa datang kerumah kakak kandung korban tempat dimana bunga tinggal. Pada saat terdakwa 
melihat korban sedang tidur diruang TV lalu terdakwa menggendong korban masuk ke kamar. Selanjutnya pada pukul 04.00 wib terdakwa membaringkan tubuh korban dan terdakwa tidur disamping korban sambil memeluk korban. Lalu korban terbangun dan mengatakan "Bapak ini kok peluknya kok kayak gitu kita mau tidur". Sambil tangan korban mendorong tangan terdakwa, lalu terdakwa mengatakan "kau ini kek mana dulu udah hancur masa depanmu". Lalu terdakwa meremasremas pantat korban dan mengatakan "mulut mu ini nanti aku pecahkan". Lalu korban menangis, terdakwa keluar kamar dan kembali ke kamar sambil mengambil jilbab korban dan melipat-lipatnya kemudian menutup mata korban dengan jilbab sehingga korban tidak dapat melihat. Selanjutnya terdakwa mengatakan " udah siap kan matamu ku buat buta?" korban menjawab sambil menangis " pak, jangan pak?" lalu terdakwa mengatakan "sengaja aku pulang ini memang mau buat kamu cacat, kenapa diam aja jawab ooo berarti kalau tidak jawab siap aku buat buta!!" selanjutnya saksi korban menangis dan membuka tutup mata sambil mengatakan "capeklah bunga ngomong sama bapak dari tadi bunga ngomong sama bapak tidak ada bapak open" lalu terdakwa semakin marah dan terdakwa memasak air panas, setelah itu terdakwa membawa cangkir yang berisikan air panas dan akan menyiram mata korban. Lalu korban menangis dan meminta maaf. Selanjutnya terdakwa melaksanakan jarimah pemerkosaannya. Korban menangis sambil mengatakan "jangan pak" terdakwa menjawab "udah diam aja kau udah hancur, ku bawa ke medan ku jadikan lonte kau".

Bahwa selanjutnya pada hari kamis tanggal 5 November 2015 pukul 04.30 wib terdakwa pulang ke rumah kakak kandung terdakwa. Kemudian terdakwa masuk ke dalam kamar akan tetapi kakak kandung korban mengatakan "tidur diluar aja ngapain tidur didalam sempit disitu". Terdakwa menjawab "nggak apa-apa aku tidur dibawah aja" dan setelah itu terdakwa mematikan lampu kamar dan menutup rapat pintu. Kemudian terdakwa tidur disamping korban, dan memeluk serta merabaraba korban. Korban menolak, lalu terdakwa mengatakan "tidak berubah-berubah ya" setelah itu terdakwa marah sambil memukul korban dan mengatakan "hari ini betul-betul tidak ada ampun, pilih mana mau kumatikan atau ku jadikan lonte di medan!!" selanjutnya korban mengatakan bahwa ia masih mau bersekolah akan tetapi terdakwa tidak menghiraukan dan melaksanakan jarimah pemerkosaannya. ${ }^{23}$

Berdasarkan kronologis singkat diatas jelas bahwa ayah kandung (terdakwa) telah melakukan persetubuhan dengan anak kandungnya secara paksa dengan ancaman kekerasan dan kekerasan (tindakan memukul). Penuntut Umum menuntut terdakwadengan Pasal 49 jo. Pasal 1 ke-30 dan ke-25 qanun Aceh Nomor 6 Tahun 2016 tentang Hukum Jinayat.Dalam pertimbangannya majelis hakim menjelaskan setiap unsur-unsur dari Pasal 49 tersebut yaitu:

1. Setiap orang

2. Unsur dengan sengaja

23 Surat Dakwaan Rek.Perk.PDM20/LNGSA/02/2016 tanggal 10 Februari 2016 
3. Unsur melakukan jarimah pemerkosaan

4. Unsur terhadap yang memiliki mahram

Ha-hal yang memberatkan yang tercantum dalam putusan adalah :

1. Perbuatan terdakwa telah merusak masa depan korban

2. Perbuatan terdakwa dilakukan terhadap mahram atau anak kandung sendiri

3. Perbuatan terdakwa menimbulkan trauma berkepanjangan pada diri saksi korban

4. Terdakwa tidak mempunyai rasa penyesalan terhadap perbuatannya

Sedangkan hal-hal yang meringankan yaitu:

1. Terdakwa bersikap sopan selama persidangan

2. Terdakwa belum pernah mendapat hukuman uqubat (pidana)

Dalam putusan Nomor

05/JN/2016/MS.Lgs majelis hakim memutuskan menjatuhkan uqubat (pidana) kepada terdakwa penjara selama 180 (serauts delapan puluh) bulan atau 15 (lima belas) tahun.

Berdasarkan hasil wawancara dengan Bapak Anwar terkait pertimbangan hakim dalam memutuskan suatu perkara beliau mengatakan : "Hakim akan memeriksa terdakwa untuk membuktikan dakwaan yang dituntut oleh penuntut umum dipersidangan, untuk setiap unsur dari Pasal yang didakwakan. Jika terbukti hakim akan mempertimbangkan hal-hal yang memberatkan dan yang meringankan." 24

Selanjutnya menanggapi perbedaan hukuman antara Undang-Undang Nomor 35 Tahun 2014 dengan qanun Nomor 6 Tahun 2014, Bapak Anwar menjelaskan "bahwa hakim pada umumnya tidak keluar dari hukum positif yang telah ditetapkan. Hukuman 180 penjara (15 tahun) penjara adalah hukuman yang tergolong maksimal

${ }^{24}$ Wawancaraa Hakim Anwar Syamaun Mahkamah Syar'iyah Langsa. (diolah) dari hukuman 200 bulan penjara (16 tahun, 6 bulan). 25

Berdasarkan uraian diatas diketahui bahwa walaupun hakim diberikan kewenangan untuk melakukan penemuan hukum yaitu menggali nilai-nilai keadilan yang ada dalam masyarakat, namun kewenangan ini digunakan untuk suatu ketentuan hukum yang belum diatur dalam hukum positif. Sedangkan bagi pelaku pemerkosa terhadap anak kandung telah diatur dalam qanun. Maka hakim berpedoman pada qanun. mungkin akan berbeda apabila ancaman maksimal dalam qanun sama dengan ancaman maksimal dalam Undang-Undang Nomor 35 Tahun 2014 (payung hukum perlindungan anak), khususnya bagi orangtua yang melakukan pemerkosaan terhadap anak.

Alasan yang paling logis pemberatan hukuman terhadap AS adalah karena AS melakukan pemerkosaan terhadap anak kandungnya. Bahwa sebagai orang tua AS seharusnya berkewajiban melindungi dan memelihara anak semasa dalam kandungan maupun sesudah dilahirkan, anak berhak atas kesejahteraan, perawatan, asuhan dan bimbingan berdasarkan kasih sayang baik dalam keluarganya, maupun dalam asuhan khusus untuk berkembang secara wajar. Namun dalam hal ini AS justru melakukan perbuatan kejam dan keji terhadap anak kandungnya.

Undang-Undang Nomor 35 Tahun 2014 adalah umbrella law dalam upaya perlindungan terhadap anak. UndangUndang ini merupakan harapan besar masyarakat demi terwujudnya keadilan bagi anak. Pasal pemberatan yang dihadirkan dalam undang-undang ini merupakan desakan masyarakat terdahap peningkatan kekerasan seksual terhadap anak dimana pelakunya adalah orang-orang yang seharusnya secara langsung pihak yang

${ }^{25}$ Wawancaraa Hakim Anwar Syamaun Mahkamah Syar'iyah Langsa. (diolah) 
menyelenggarakan perlindungan terhadap anakyaitu Orang Tua, Wali, pengasuh Anak, pendidik, atau tenaga kependidikan.

Sangat disayangkan justru hukuman yang diberikan qanun masih jauh dari semangat dalam Undang-Undang Nomor 35 Tahun 2014. Sehingga dapat dikatakan sanksi pidana bagi ayah sebagai pelaku pemerkosa terhadap anak kandungnya, khusus di provinsi Aceh lebih rendah dari pada 32 provinsi lainnya di Indonesia. Padalah dampak yang diterima korban (anak kandung) baik secara fisik, psikis, cidera tubuh dan dampak sosial tidak ada perbedaan di Aceh maupun di provinsi lainnya.

Konsep keadilan dan legalitas menurut Hans Kelsen yaitu untuk menegakkan diatas dasar suatu yang kokoh dari suatu tatanan sosial tertentu, menurut Hans pengertian "keadilan" bermaknakan leglitas. Suatu peraturan umum adalah "adil" jika benar-benar diterapkan, sementara itu suatu peraturan umum adalah "tidak adil" jika diterapkan pada suatu kasus dan tidak diterapkan pada kasus lain yang serupa. Konsep keadilan dan legalitas inilah yang diterapkan dalam hukum nasional bangsa Indonesia, yang memaknai bahwa peraturan hukum nasional dapat dijadikan sebagai payung hukum (umbrella law) bagi peraturan peraturan hukum nasional lainnya sesuai tingkat dan derajatnya peraturan hukum itu memiliki daya ikat terhadap materi-materi yang dimuat (materi muatan) dalam peraturan hukum tersebut. ${ }^{26}$

Menurut Satochid Kartanegara dan pendapat-pendapat para ahi hukum terkemuka dalam hukum pidana, mengemukakan teori tujuan pemidanaan atau penghukuman dalam hukum pidana dikenal ada tiga aliran yaitu : ${ }^{27}$

${ }^{26}$ Marwan Hukum, Teori Hukum (dari Perspektif Kebijakan, Perbandingan dan Harmonisasi Hukum Pidana), Referensi (Jakarta: Gaung Persada Press Group), 2014, hal 81.

27Ibid, hal 90.
1. Teori Absolute

Teori ini memberikan pandangan bahwa penjatuhan pidana sematamata karena seseorang telah melakukan suatu kejahatan atau tindak pidana. Immanuel Kant mengatakan bahwa pidana menghendaki agar setiap perbuatan melawan hukum harus dibalas karena merupakan suatu keharusan yang bersifat mutlak yang dibenarkan sebagai pembalasan. Oleh karena itu konsekuensinya adalah setiap pengecualian dalam pemidanaan yang bertujuan untuk mencpaai tujuan tertentu selain pembalsan harus dikesampingkan.

2. Teori Relatif

Menurut teori ini penjatuhan pidana bukanlah sekedar untuk melakukan pembalsan atau pengimbalan. Pembalasan itu sendiri tidak mempunyai nilai tetapi hanya sebagai sarana melindungi kepentingan masyarakat. Tujuan pemidanaan menurut teori ini adalah menakut-nakuti seseorang suapaya tidak melakukan tindka pidana baik pelaku sendiri maupun masyarakat. Dan memperbaiki, mendidik pelaku sehingga menjadi orang yang baik dalam masyarakat.

3. Teori gabungan

Teori ini muncul sebagai reaksi dari teori sebelumnya yang kurang dapat memuaskan dan menjawab mengenai tujuan pemidanaan. Tokoh utama yang mengajukan teori ini adalah Pellegrino Rossi. Pandangan teori ini adalah :

a. Dalam rangka menentukan benar dan atau tidaknya asas pembalasan, mensyaratkan agar setiap kesalahan harus dibalas dengan kesalahan, maka terhadap mereka telah meninjau tentang pentingnya suatu pidana dari sudut kebutuhan masyarakat dan asas kebenaran. 
b. Suatu tindak pidana menimbulkan hak bagi negara untuk menjatuhkan pidana dan pemidanaan merupakan suatu kewajiban apabila telah memiliki tujuan yang dikehendaki

c. Dasar pembenaran dari pidana terletak pada faktor tujuan yakni mempertahankan tertib hukum.

Selanjutnya Rossi berpendapat bahwa pemidanaan merupakan pembalasan terhadap kesalahan yang teah dilakukan, sedangkan berat ringannya pemidanaan harus sesuai dengan absolute justice (keadilan yang mutlak), yang tidak melebihi sosial justice (keadilan yang dikehendaki oleh masyarakat).

Berdasarkan uraian teori gabungan diatas, disimpulkan bahwa pemidanaan memberikan kepuasan moral kepada masyarakat sesuai rasa keadilan. Memberikan rasa aman kepada masyarakat. Memperbaiki pribadi terpidana dan secara preventifnya mencegah niat untuk melakukan tindak pidana.

Anak merupakan pihak yang paling rentan dalam masyarakat, anak memiliki kelemahan untuk mengutarakan tindak pidana yang terjadi padanya karena rasa takut, anak memiliki kelemahan untuk melawan orang dewasa yang melakukan tindak pidana kepadanya karena tidak cukup kuat untuk melawan. Tindak pidana pemerkosaan di Indonesia belum mengakomodir pemulihan ataupun rehabilitasi terhadap korban. Hak restitusi yang telah diatur masih belum dilaksanakan. Satu-satunya harapan adalah pelaku menerima hukuman berdasarkan keadilan yang mutlak sesuai dengan keadilan yang dikehendaki masyarakat

\section{IV.Penutup}

\section{A. Kesimpulan}

1. KUHP maupun Qanun Jinayah samasama mengatur bahwa tindak pidana pemerkosaan terjadi di luar perkawinan. Artinya rumusan KUHP dan Qanun tidak mengenal marital rape (perkosaan dalam perkawinan). Perbedaan rumusan pemerkosaan antara KUHP dan Qanun yakni memuat unsur "dengan sengaja" melakukan pemerkosaan, sedangkan dalam KUHP, bagian inti deliknya "dengan kekerasan atau ancaman kekerasan" memaksa seorang wanita untuk bersetubuh dengan dia. Jadi perbuatan tersebut dilakukan dengan unsur paksaan.

2. Sanksi pidana antara UndangUndang Nomor 35 Tahun 2014 dengan Qanun Nomor 6 Tahun 2014 yaitu: Sanksi pidana maksimal dalam Undang-Undang Nomor 35 Tahun 2014 bagi pelaku pemerkosaan terhadap anak yang dilakukan oleh Orang Tua, Wali, pengasuh Anak, pendidik, atau tenaga kependidikan diperberat $1 / 3$ menjadi yaitu 20 (dua puluh tahun) penjara dan denda $\mathrm{Rp}$ 5.000.000.000,00 (lima miliar rupiah).

Pelaku pemerkosaan terhadap anak yang dalam Undang-Undang Nomor 35 Tahun 2014 yang dikenakan pemberatan, adalah pelaku yang disebutkan secara konkrit yaitu Orang Tua, Wali, pengasuh Anak, pendidik, atau tenaga kependidikan.

3. Dalam qanun hukum jinayat sanksi pidana cambuk maksimal 200 kali, denda 2.000 gram emas murni (sampai dengan tulisan ini diturunkan, emas murni per gram adalah Rp. 552.000,- x 2.000 gram emas = Rp.1.104.000.000) sedangkan sanksi maksimal penjara adalah 200 bulan (16 tahun, 6 bulan). Pelaku pemerkosaan terhadap anak yang dalam Undang-Undang Nomor 35 Tahun 2014 yang dikenakan pemberatan, adalah pelaku yang disebutkan secara konkrit yaitu Orang Tua, Wali, pengasuh Anak, pendidik, atau tenaga kependidikan. Pelaku pemerkosaan terhadap anak dalam qanun hukum jinayat Nomor 6 Tahun 2014, tidak ada pasal pemberatan bagi pelaku pemerkosaan dalam kategori seperti dalam Undang-Undang Nomor 35 Tahun 2014 yaitu Orang Tua, Wali, pengasuh Anak, pendidik, atau 
tenaga kependidikan. Sanksi pidana bagi pemerkosa anak dalam Pasal 49 dan Pasal 50 memiliki ancaman hukuman yang sama.

\section{B. Saran}

1. Dalam mewujudkan kesejahterahan bangsa kiranya harus ada sinkronisasi antara kebijakan pemerintah dengan keadaan sistem sosial saat ini. Maksudnya adalah bahwa aplikasi ancaman pidana yang dijatuhkan kepada pelaku tindak pidana harus memiliki pengaruh sesuai dengan masingmasing tujuan pemidanaan.

2. Perlunya sosialisasi yang aktif untuk menegaskan peraturan perundang-undangan tentang perlindungan anak kepada masyarakat, dengan tujuan pencegahan, penanggulangan dan penurunan jumlah korban kejahatan seksual khususnya yang dapat mengancam masa depan anak-anak bangsa.

3. Berdasarkan uraian diatas dapat terlihat bahwa sanksi hukum dalam Undang-Undang Nomor 35 Tahun 2014 lebih berat dari Qanun Nomor 6 Tahun 2014 tentang hukum jinayat. Diharapkan dilakukan peninjauan ulang terhadap sanksi pidana dalam Qanun Nomor 6 Tahun 2014 tentang Hukum Jinayat.

\section{DAFTAR PUSTAKA}

\section{A. Buku-Buku}

Chazawi, A., 2002, Pelajaran Hukum Pidana, Raja Grafindo Persada, Jakarta.

Sukardja, A., dan MujarIbnu S., 2012, Tiga Kategori Hukum: Syariat, Fikih, \& Qanun, Sinar Grafika, Jakarta.

Poernomo, B., 1993, Asas-asas Hukum Pidana, Penerbit Balai Aksara, Jakarta.

Eddy O.S. Hiariej, 2014, Prinsip-prinsip Hukum Pidana, Cahaya Atma Pusaka, Yogyakarta.

Yuwono, I.D., 2015. Penerapan Hukum Dalam Kasus Kekerasan Seskual Terhadap Anak, PT Buku Seru, Jakarta.
Ibrahim, J., 2008, Teori dan Metodologi Penelitian Hukum Normatif, Banyumedia Publishing, Malang.

Lamintang, 1997, Dasar-dasar Hukum Pidana Indonesia, PT Citra Adiyta Bakti, Bandung.

Marwan, 2014, Hukum, Teori Hukum (dari Perspektif Kebijakan, Perbandingan dan Harmonisasi Hukum Pidana), Referensi (Gaung Persada Press Group), Jakarta.

M. Ghufron H Kordi K, 2015, Durhaka Kepada Anak (Refleksi mengenai Hak\&Perlindungan Anak), Pustaka Baru Press, Yogyakarta

Thamrin, M.I., dan M. Farid, 2010, Panduan Bantuan Hukum Bagi Paralegal, Lembaga Bantuan Hukum Yogyakarta Bekerja Sama dengan TIFA Fondation, Yogyakarta.

Adi, R., 2000, Metode Penelitian Sosial dan Hukum, Granit, Jakarta.

Soekanto, S., 2006, Pengantar Penelitian Hukum, UI Press, Jakarta.

Hartono, S., 1994, Penelitian Hukum Indonesia Pada Akhir ke- 20, Alumni, Bandung.

Lubis, Z., dan Bakti R., 2016, Dasar-dasar Hukum Acara Jinayah, Prenadamedia Group.

\section{B. Undang-Undang}

R. Soesilo, Kitab Undang-Undang Hukum Pidana (KUHP) serta KomentarKomentarnya Lengkap Pasal Demi Pasal, Politeia, Bogor, 1996.

Undang-Undang Nomor 35 Tahun 2014 Tentang Perlindungan Anak

Qanun Nomor 6 Tahun 2014 Tentang Hukum Jinayat

\section{Internet}

http://news.liputan6.com/read/2396014/k omnas-pa-2015-kekerasan-anaktertinggi-selama-5-tahun-terakhir

http://situs.kesrepro.info/gerdervaw/mater i/perkosaan, 